\title{
Connexin 43 Expression in Human Hypertrophied Heart Due to Pressure and Volume Overload
}

\author{
C. VETTER $^{1 *}$, M. ZWEIFEL ${ }^{2 *}$, C. ZUPPINGER $^{1}$, T. CARREL $^{1}$, D. MARTIN $^{3}$, \\ J.-A. HAEFLIGER ${ }^{3}$, E. DELACRÉTAZ ${ }^{1}$ \\ "These authors contributed equally to this work
}

${ }^{1}$ Swiss Cardiovascular Center Bern, University Hospital, Bern, Switzerland, ${ }^{2}$ Division of Medical Oncology, University Hospital, Zurich, Switzerland, ${ }^{3}$ Department of Internal Medicine, University Hospital, Lausanne, Switzerland

Received July 25, 2008

Accepted January 21, 2009

On-line February 27, 2009

\section{Summary}

Left ventricular hypertrophy (LVH) is due to pressure overload or mechanical stretch and is thought to be associated with remodeling of gap-junctions. We investigated whether the expression of connexin $43(\mathrm{C} \times 43)$ is altered in humans in response to different degrees of LVH. The expression of $\mathrm{Cx} 43$ was analyzed by quantitative polymerase chain reaction, Western blot analysis and immunohistochemistry on left ventricular biopsies from patients undergoing aortic or mitral valve replacement. Three groups were analyzed: patients with aortic stenosis with severe LVH $(n=9)$ versus only mild LVH $(n=7)$, and patients with LVH caused by mitral regurgitation $(n=5)$. Cx43 mRNA expression and protein expression were similar in the three groups studied. Furthermore, immunohistochemistry revealed no change in $\mathrm{Cx} 43$ distribution. We can conclude that when compared with mild LVH or with LVH due to volume overload, severe LVH due to chronic pressure overload is not accompanied by detectable changes of $\mathrm{C} \times 43$ expression or spatial distribution.

\section{Key words}

Gap junction • Connexin43 • Cardiac hypertrophy • Aortic stenosis • Remodeling

\section{Corresponding author}

Etienne Delacrétaz, Swiss Cardiovascular Center Bern, University Hospital, CH-3010 Bern, Switzerland. Fax: +4131632 4299. E-mail: etienne.delacretaz@insel.ch

\section{Introduction}

Mechanical stress during left ventricular pressure overload is one of the most potent stimuli leading to left ventricular hypertrophy (LVH) and is associated with electro-mechanical remodeling (De Mello 1999, Dupont et al. 2001, Peters et al. 1997, Peters and Wit 2000, Sepp et al. 1996, Teunissen et al. 2004). Cardiac gap junction remodeling was demonstrated in response to mechanical stress in vitro (Saffitz et al. 1999). However, most data are derived from animal experiments. There are conflicting data regarding connexin regulation in relation to cellular hypertrophy in vivo. In cardiomyocytes of neonatal mice, acute hypertrophic response elicited by VEGF or stretch increases connexin $43(\mathrm{Cx} 43)$ expression, leading to an increased velocity of propagation of the depolarizing wave front (Darrow et al. 1996, Zhuang et al. 2000). In rat models of chronic $\mathrm{LVH}$, however, $\mathrm{Cx} 43$ expression was not increased (Haefliger et al. 1997b, Haefliger et al. 1999). In humans, Cx43 expression is reduced in ventricular myocardium from hypertrophied and ischemic hearts (Peters et al. 1993, Teunissen et al. 2004). However, this was shown to be most likely due to ischemia (Peters 1996). Thus, little is known on the regulation of the cell-to-cell communication in response to $\mathrm{LVH}$.

The aim of our study was to prospectively investigate the expression of $\mathrm{Cx} 43$ in left ventricular biopsies from patients with chronic left ventricular 
pressure overload with severe LVH versus mild LVH caused by moderate to severe aortic stenosis, compared to patients with LVH due to left ventricular volume overload related to severe mitral vave regurgitation.

\section{Methods}

Patients selection and human left ventricular myocardial tissue

Patients undergoing aortic valve replacement for severe aortic stenosis without heart failure and without ischemic heart disease were enrolled in the study. They were assigned to two groups according to the degree of LVH. Structural cardiac data were obtained using a commercially available ultrasound system (Acuson 128/XP10c, Acuson, Mountain View, CA, USA) with a 3.5 MHz transducer frequency for M-mode and $2.5 \mathrm{MHz}$ for Doppler recordings. M-mode tracings were quantified according to the recommendations of the American Society of Echocardiography. Left ventricular mass was calculated using the cube formula and overestimation was corrected using the equation proposed by Devereux et al. (1986). Patients with mitral regurgitation undergoing mitral valve replacement were enrolled as subjects with LVH due to volume overload. At the time of cardiac surgery, two biopsies from every patient were taken from the endocardial aspect of the septum of the left ventricle and immediately snap frozen in liquid nitrogen for subsequent analysis. Informed consent was obtained from all patients before inclusion in the study. The protocol used for the experiments complies with the Declaration of Helsinki and was approved by the Human Ethical Committee of the University of Bern.

Western blot analysis and quantification of connexin 43 protein

Frozen left ventricular tissue was powdered and solubilized in a buffer containing $5 \%$ SDS supplemented with $5 \mathrm{mM}$ EDTA. The DC protein assay reagent kit (Bio-Rad Laboratories, Inc., Hercules, CA, USA) was used to determine the protein content. Aliquots of human heart total protein were heated at $95{ }^{\circ} \mathrm{C}$ for $5 \mathrm{~min}$ in loading buffer, fractionated by electrophoresis in a $12.5 \%$ polyacrylamide gel and immunoblotted onto Immobilon PVDF membranes (Millipore, Billerica, MA, USA) overnight at a constant voltage of $20 \mathrm{~V}$. Membranes were incubated for one hour at room temperature in PBS containing $5 \%$ dry milk and $0.1 \%$ Tween 20 (blocking buffer) and then incubated overnight at $4{ }^{\circ} \mathrm{C}$ with a polyclonal rabbit antibody directed against the C-terminus of $\mathrm{Cx} 43$ (Millipore, Billerica, MA, USA) in blocking buffer (final concentration $5 \mu \mathrm{g} / \mathrm{ml}$ ). The membrane was then incubated for $45 \mathrm{~min}$ at room temperature with horseradish peroxidase (HRP)-coupled goat anti-rabbit immunoglobulins (DAKO, Glostrup, Danmark) in a dilution of 1:2000 and the bands visualized using the SuperSignal West Pico Chemiluminescent Substrate (Pierce Socochim, Rockford, IL, USA). For the detection of $\beta$-tubulin, the membrane was stripped using $3.25 \mathrm{ml} 1 \mathrm{M}$ Tris-Cl $\mathrm{pH}$ $6.7,10 \mathrm{ml}$ SDS $10 \%$, and $350 \mu \mathrm{l} \beta$-mercaptoethanol in $50 \mathrm{ml} \mathrm{H}_{2} \mathrm{O}$ and immunoblotting was performed using a polyclonal rabbit anti-human $\beta$-tubulin antibody (SigmaAldrich, Inc., St. Louis, MO, USA). For the quantification of immunoblot bands, pixel densities of scanned immunoblot membranes were analyzed using the TinyQuant $^{\odot}$ software (Norman Iscove, University Health Network, The Ontario Cancer Institute, Toronto, Canada).

Immunofluorescence staining for the detection of connexin 43 protein on histologic sections

For indirect immunofluorescence labeling, $10 \mu \mathrm{m}$ cryosections were cut in parallel to the fiber's longitudinal axis. Sections were incubated for $30 \mathrm{~min}$ in phosphate-buffered saline (PBS) containing $5 \%$ bovine serum albumin (BSA). Sections were then incubated for $12 \mathrm{~h}$ at $4{ }^{\circ} \mathrm{C}$ with a polyclonal rabbit antibody directed against the C-terminus of $\mathrm{Cx} 43$ (Millipore, Billerica, MA, USA) in PBS (final concentration $5 \mu \mathrm{g} / \mathrm{ml}$ ). As secondary antibody, a FITC-labeled goat anti-rabbit IgG antibody was used (Molecular Probes, Eugene, OR, USA; diluted 1:500). Three sections per patient, and 10 high power fields per section were visualized, and the distribution pattern was morphologically analyzed with regard to the localized expression of $\mathrm{Cx} 43$ at the poles, and the borders of the myocardial cells, respectively.

Real time reverse transcription-polymerase chain reaction (RT-PCR) for the quantification of connexin 43 $m R N A$

Quantitative RT-PCR was performed as previously described (Zweifel et al. 2002). Frozen left ventricular tissue was homogenized in a $4 \mathrm{M}$ guanidine hydrothiocyanate buffer containing $25 \mathrm{mM}$ sodium citrate and $100 \mathrm{mM} \quad \beta$-mercaptoethanol. Total RNA was extracted by the acid guanidium isothiocyanate method and yields were evaluated by absorbance at $260 \mathrm{~nm}$. 
Table 1. Clinical characteristics of patients according to the different groups.

\begin{tabular}{lcccc}
\hline & $\begin{array}{c}\text { MR, LVH } \\
(\mathbf{n}=\mathbf{5})\end{array}$ & $\begin{array}{c}\text { AS, mild LVH } \\
(\mathbf{n = 7})\end{array}$ & $\begin{array}{c}\text { AS, severe LVH } \\
(\mathbf{n}=\mathbf{9})\end{array}$ & Significance (p) \\
\hline Age, years & $75 \pm 11$ & $70 \pm 7$ & $73 \pm 8$ & $\mathrm{n} / \mathrm{s}$ \\
Gender, males/females & $3 / 1$ & $3 / 4$ & $5 / 4$ & $\mathrm{n} / \mathrm{s}$ \\
BMI, $\mathrm{kg} / \mathrm{m}^{2}$ & $23 \pm 3$ & $29 \pm 3$ & $26 \pm 3$ & $\mathrm{n} / \mathrm{s}$ \\
LVMI, $/ \mathrm{m}^{2}$ & $162 \pm 22$ & $121 \pm 5$ & $179 \pm 57$ & $\mathrm{n} / \mathrm{s}$ \\
LVEF, $\%$ & $71 \pm 9$ & $62 \pm 13$ & $67 \pm 8$ & $\mathrm{n} / \mathrm{s}$ \\
Mean transaortic & $\mathrm{n} / \mathrm{a}$ & $37 \pm 4$ & $47 \pm 5$ & $\mathrm{n} / \mathrm{a}$ \\
gradient (mm Hg) & 3 & 3 & 7 & \\
Arterial hypertension & & & \\
\hline
\end{tabular}

MR - mitral regurgitation; LVH - left ventricular hypertrophy; AS - aortic stenosis; BMI - body mass index; LVMI - left ventricular mass index; LVEF - left ventricular ejection fraction; n/s - not significant; n/a - not applicable.

Since Cx43 pre-mRNA does not contain any introns, a DNA digestion step was performed before reverse transcription in order to remove any contaminant genomic DNA which would also be amplified by the primers and probe during PCR. Quantitative real time RT-PCR was performed for human Cx43 mRNA, eukaryotic 18S rRNA, and human glyceraldehyde-3phosphate dehydrogenase (GAPDH) mRNA. Primers and the fluorescent FAM-labeled probe for PCR of the reverse transcribed $\mathrm{Cx} 43 \mathrm{mRNA}$ were designed in-house from published sequences using the PrimerExpress software (Applied Biosystems, Foster City, CA, USA). The sequences of the primers and probe for $\mathrm{Cx} 43$ (GenBank accession number AF151980, National Center for Biotechnology Information, National Library of Medicine, 8600 Rockville Pike, Bethesda, MD 20894, USA, www.ncbi.nlm.nih.gov/Genbank/) were 5'-GCCC ACATCAGGTGGACTGT-3’ (sense), 5‘-AAGGACACC ACCAGCATGAAG-3“ (antisense), 5‘-CTCGCCCCA CGGAGAAAACCATC-3` (fluorescence labeled probe). Primers and probes for the reverse transcribed $18 \mathrm{~S}$ rRNA and GAPDH mRNA were purchased as predeveloped assay reagent (PDAR) from Applied Biosystems. Real time PCR was performed using the TaqMan Universal PCR Master Mix with $80 \mathrm{ng}$ of reverse transcribed input RNA, and a concentration of primers and probes of 900 $\mathrm{nM}$ and $200 \mathrm{nM}$, respectively, in a final reaction volume of $25 \mu \mathrm{l}$ in a ABI PRISM 7700 Sequence Detector (Applied Biosystems) according to the manufacturer's protocol. PCR amplification was performed for 40 cycles. PCR amplifications of the constitutively expressed $18 \mathrm{~S}$ and GAPDH mRNA were performed after reverse transcription as a measure of input RNA. Relative quantity of $\mathrm{Cx} 43 \mathrm{mRNA}$ was then expressed as ratio of the Cx43 mRNA quantity to the quantity of the housekeeping genes $18 \mathrm{~S}$ and GAPDH, respectively.

\section{Statistical analysis}

Data are expressed as mean \pm S.E.M. Kruskal Wallis and Mann Whitney-U tests were applied for the analysis of variation among the groups, and to assess the significance (p) of the difference between two groups, respectively. $p<0.05$ value was considered significant.

\section{Results}

Sixteen patients undergoing aortic valve replacement for severe aortic stenosis were enrolled in the study. They were assigned to two groups according to the degree of LVH, nine with severe LVH, and seven with mild LVH. Five additional patients with mitral regurgitation undergoing mitral valve replacement were enrolled as subjects with LVH due to volume overload. None of the patients had previous ventricular arrhythmic disorders, and none of them had ischemic heart disease. All patients had a normal systolic left ventricular function. The clinical characteristics of the patients are summarized in Table 1. Statistical analysis for age, QRS duration, and left ventricular ejection fraction did not show any significant differences between the three groups. The mean aortic valve gradients are similar in both groups with aortic stenosis. The mean left ventricular mass is higher in the group with aortic stenosis and severe $\mathrm{LVH}$, compared to the group with aortic stenosis and mild LVH, and the group with mitral valve disease, respectively. Western blot (Fig. 1a) and 


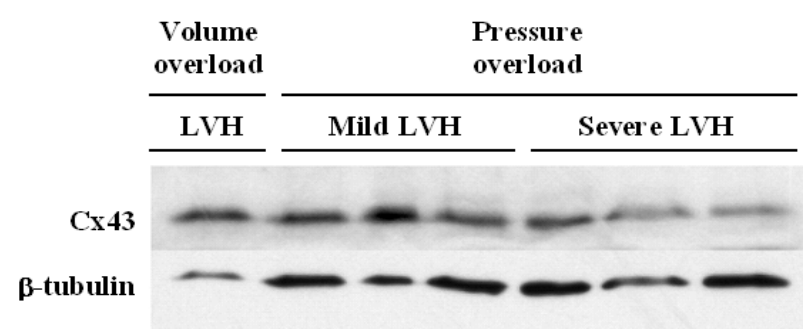

Fig. 1a. Representative bands from Western blot for Cx43 protein detection in left ventricular biopsies from different patients of the three groups: patients with volume overload due to mitral regurgitation, patients with aortic stenosis and mild left ventricular hypertrophy, and patients with aortic stenosis and severe left ventricular hypertrophy.

band density analysis (Fig. 1b) revealed no significant differences in $\mathrm{Cx} 43$ expression in left ventricular tissue between all three groups.

Representative images of left ventricular sections from the three groups, immunostained with a specific antibody directed against $\mathrm{Cx} 43$, are shown in Figure 2. $\mathrm{Cx} 43$ is present in all groups and is confined to the cell poles, whereas only little expression is found at the lateral cell border. The distribution pattern of $\mathrm{Cx} 43$ is similar in all three groups, as assessed by morphologic microscopic evaluation.

Real time RT-PCR for the quantification of $\mathrm{Cx} 43$ in relation to the constitutively expressed house keeping genes (18S and GAPDH) did not show any significant difference between the three groups (Fig. 3).

\section{Discussion}

In this study, large subendocardial left ventricle biopsies taken at the time of aortic or mitral valve replacement allowed us to prospectively compare $\mathrm{Cx} 43$ expression in response to different causes and degrees of $\mathrm{LVH}$, at the protein level by Western blot and immunohistochemistry, and at the mRNA level by quantitative RT-PCR.

Patients with chronic LV pressure overload due to aortic stenosis with severe or mild $\mathrm{LVH}$, respectively, as well as patients with volume overload due to mitral regurgitation were compared. None of the patients had concomitant coronary heart disease or impairment of left ventricular function. Expression levels of $\mathrm{Cx} 43$ protein and $\mathrm{Cx} 43$ mRNA were identical in patients with $\mathrm{LVH}$ due to chronic pressure overload and in patients with LVH due to chronic volume overload. Moreover, the expression of $\mathrm{Cx} 43$ was similar in patients with severe LVH compared to patients with mild LVH, and in

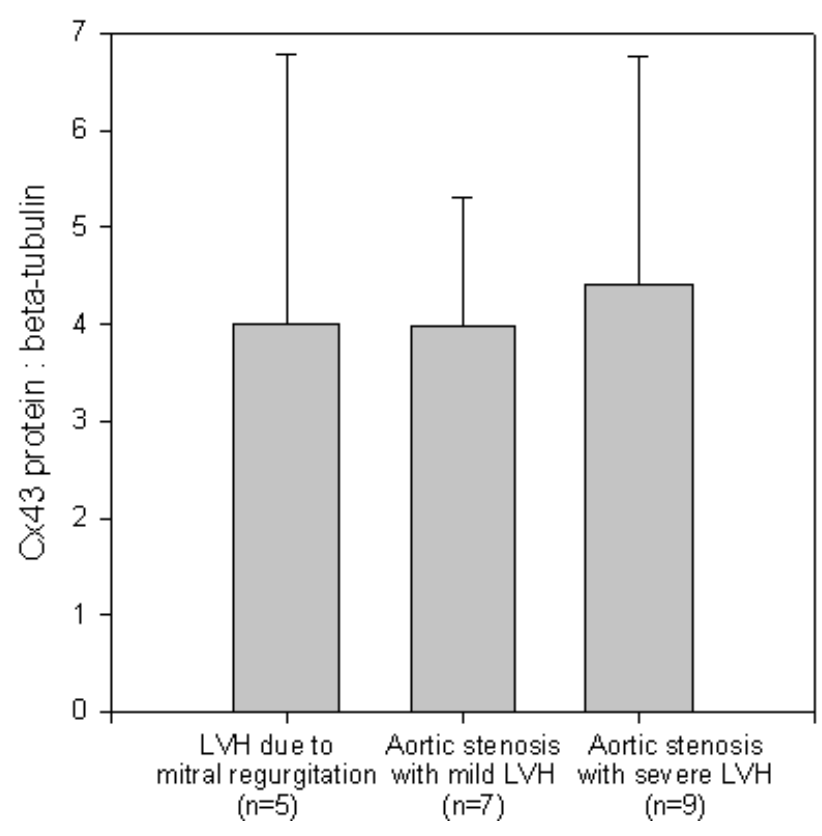

Fig. 1b. Quantification of $\mathrm{Cx} 43$ protein expression in relation to $\beta$-tubulin expression by band pixel density analysis from scanned Western blots for $\mathrm{Cx} 43$ protein detection in left ventricular biopsies from the three different groups.

patients with chronic LV pressure overload versus chronic LV volume overload. Finally, there was no change in $\mathrm{Cx} 43$ distribution. Thus, in our study in humans, severe LVH as compared to mild LVH is not associated with a relevant remodeling of $\mathrm{Cx} 43$ mediated cell-to-cell communication.

Conflicting data on $\mathrm{Cx} 43$ expression have previously been reported in animals with ventricular structural abnormalities (Formigli et al. 2003, Haefliger et al. 1997a, b, Uzzaman et al. 2000). Increased synthesis of $\mathrm{Cx} 43$ and increased conduction velocity have been demonstrated in vitro in hypertrophic response to stretch and to factors stimulating cellular growth in neonatal ventricular cardiomyocytes (Darrow et al. 1996, Zhuang et al. 2000). Cx43 expression is also up-regulated in the early phase of hypertrophy in guinea pigs with renovascular hypertension. In chronic models, no significant changes in $\mathrm{Cx} 43$ expression were detected in hypertrophied hearts of rats with hypertension provoked by renal artery clipping or deoxycorticosterone/salt administration, or during inhibition of nitric oxide synthase (Haefliger et al. 1997a, b). However, 8 to 12 weeks after aortic banding, $\mathrm{Cx} 43$ was frequently displaced from its usual location at the intercaled disks to form side-to-side contacts distant from the disk (Emdad et al. 2001). Following left ventricular overload, Formigli et al. (2003) observed a short-lived increase in Cx43 

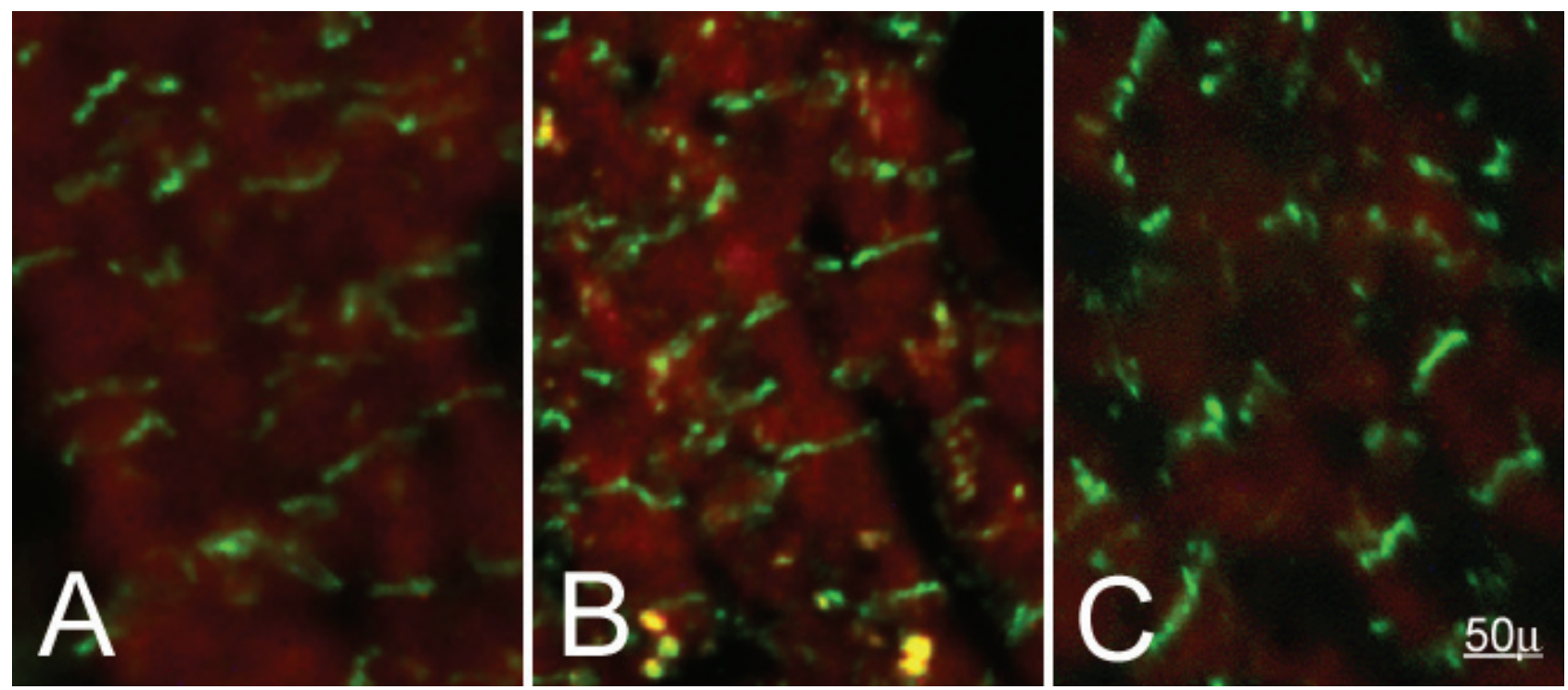

Fig. 2. Left ventricular sections were immunofluorescence stained for $\mathrm{Cx} 43$ (representative sections of the three groups). A: patient with volume overload due to mitral regurgitation. B: patient with aortic stenosis and mild left ventricular hypertrophy. C: patient with aortic stenosis and severe left ventricular hypertrophy. Cx43 (green fluorescence) is present at intercalated disks, which are seen in transverse orientation, whereas only little expression is found at the lateral cell border. Overall, Cx43 immunostaining is prominent and its distribution is similar in all groups of patients, as assessed by morphologic microscopic evaluation. Non-specific red autofluorescence of cardiomyocytes and erythrocytes is noted.

protein expression after creation of an aorto-caval fistula which decreased at day 7 , suggesting that the upregulation of $\mathrm{Cx} 43$ gap-junctional protein may represent an immediate and transient compensatory response in the early stages of hypertrophic response. Fialová et al. (2008) found an increase in $\mathrm{Cx} 43$ at the lateral cell membrane surface, particularly in spontaneously hypertensive rats (SHR). The induction of $\mathrm{Cx} 43$ expression was also observed in SHR fed with n-3 polyunsaturated fatty acids (n-3 PUFA) (Mitašíková et al. 2008). An interesting and in human studies widely unaddressed issue is the gender difference in $\mathrm{Cx} 43$ expression which was observed in left ventricles of aging rats (Tribulová et al. 2005).

Only few data are available in humans. In left ventricular biopsies of patients with hypertrophic and ischemic heart disease, $\mathrm{Cx} 43$ was found to be reduced (Peters et al. 1993). However, it appears that chronic ischemia or the presence of ventricular scars rather than cellular hypertrophy itself was responsible for these changes (Kaprielian et al. 1998, Peters 1996, Smith et al. 1991). End-stage heart failure was associated with a decrease of $\mathrm{Cx} 43$ irrespectively of the etiology of cardiomyopathy (Kostin et al. 2003). Our data in humans with chronic pressure-overload with mild versus severe LVH suggest that the development of severe hypertrophy occurs without any relevant changes in $\mathrm{Cx} 43$ expression.

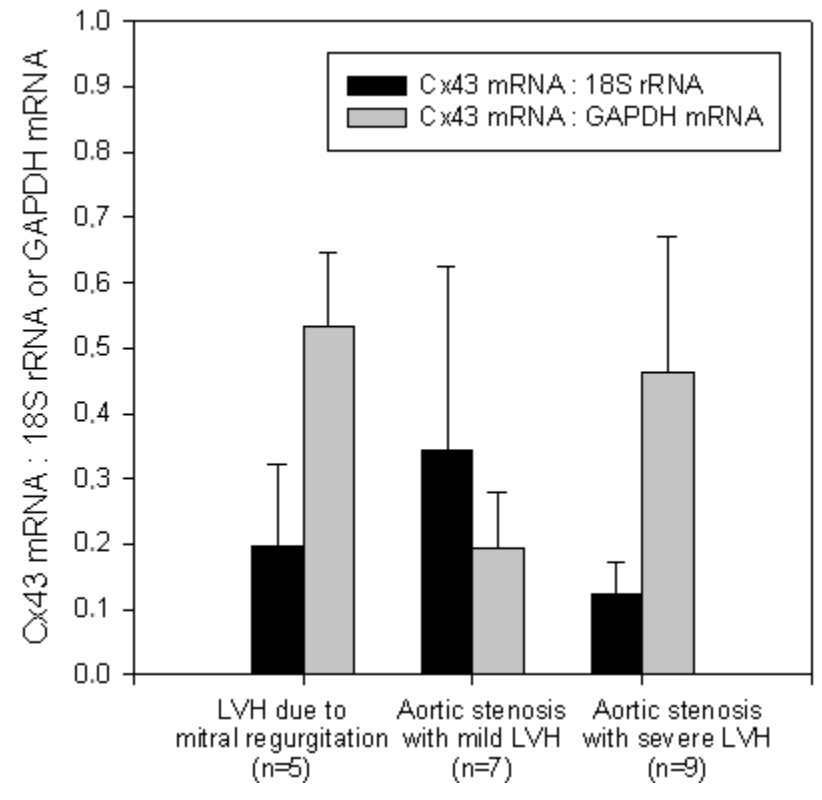

Fig. 3. Real time quantitative PCR analysis of mRNA extracted from the left ventricle of the three groups of patients. Relative quantity of Cx43 mRNA expression is calculated in relation to the rRNA, and mRNA quantity of the constitutively expressed housekeeping genes $18 \mathrm{~S}$, and GAPDH, respectively, as a measure of total input RNA. There are no significant differences between the three groups.

Changes in $\mathrm{Cx} 43$ expression have been postulated to be a mediator of electrical remodeling (Formigli et al. 2003, Saffitz et al. 1999, Severs et al. 2001). Decreased Cx43 expression or abnormal $\mathrm{Cx} 43$ distribution is associated 
with ventricular arrhythmias (Peters and Wit 2000). Disorganization of $\mathrm{Cx} 43$ was demonstrated at the border zone of myocardial infarcts in dogs and rodents, with a reduction of $\mathrm{Cx} 43$ at the intercalated disks and an increase of $\mathrm{Cx} 43$ at the lateral cell border (Matsushita et al. 1999, Peters et al. 1997). This gap junction remodeling may be associated with abnormal conduction representing a substrate for ventricular arrhythmias (Matsushita et al. 1999, Peters et al. 1997, Peters and Wit 2000). Dupont et al. (2001) and De Mello (1999) described markedly decreased levels of Cx43 mRNA and protein in the left ventricle of patients with end-stage heart failure due to ischemic heart disease and idiopathic dilated cardiomyopathy, i.e. under the conditions associated with a very high risk of sudden cardiac death due to malignant ventricular arrhythmias. Apart from disturbances in gap junction organization related to the infarction, abnormal patterns of gap junction distribution are prominent in human primary hypertrophic cardiomyopathy, a condition associated with enhanced arrhythmic tendency (Sepp et al. 1996). Conversely, in our patients with secondary $\mathrm{LVH}$, the analysis of multiple sections in large biopsies of subendocardial tissue did not reveal similar alterations in $\mathrm{Cx} 43$ distribution. Thus, secondary LVH does not seem to be associated with a potentially arrhythmogenic electrical remodeling. Indeed, the majority of patients with secondary ventricular hypertrophy survive without ventricular arrhythmias. In patients with aortic stenosis, the risk of arrhythmias and sudden cardiac death increases only late in the evolution of the disease, when the aortic stenosis becomes critical. At that stage, myocardial ischemia due to a mismatch between LVH and blood supply might be the main trigger for arrhythmias.

The absence of controls without any structural heart disease is a limitation of the study as of all such human studies because of ethical considerations. Patients without structural heart disease, or who suffer from mitral stenosis, are unlikely to undergo cardiac surgery. Moreover, only the chronic effect of pressure or volume overload on connexin expression can be analyzed. Despite of these limitations the difference in the degree of $\mathrm{LVH}$ as well as the difference in the cause of $\mathrm{LVH}$ provides us with important conclusions.

In conclusion, severe LVH due to pressure overload is not associated with detectable changes in expression or spatial distribution of $\mathrm{Cx} 43$ in comparison with mild LVH, or with LVH due to volume overload. Thus, at a chronic stage, the increase of cellular volume in $\mathrm{LVH}$ may not be associated with remodeling of $\mathrm{Cx} 43$ mediated cell-to-cell communication in humans.

\section{Conflict of Interest}

There is no conflict of interest.

\section{Acknowledgements}

This work was supported by the Swiss Heart Foundation and by grants from the Swiss National Science Foundation (632-66101.01 to ED and 31-068036.02 to J.-A. H).

\section{References}

DARROW BJ, FAST VG, KLEBER AG, BEYER EC, SAFFITZ JE: Functional and structural assessment of intercellular communication. Increased conduction velocity and enhanced connexin expression in dibutyryl cAMP-treated cultured cardiac myocytes. Circ Res 79: 174-183, 1996.

DE MELLO WC: Cell coupling and impulse propagation in the failing heart. J Cardiovasc Electrophysiol 10: 1409$1420,1999$.

DEVEREUX RB, CASALE PN, KLIGFIELD P, EISENBERG RR, MILLER D, CAMPO E, ALONSO DR: Performance of primary and derived M-mode echocardiographic measurements for detection of left ventricular hypertrophy in necropsied subjects and in patients with systemic hypertension, mitral regurgitation and dilated cardiomyopathy. Am J Cardiol 57: 1388-1393, 1986.

DUPONT E, MATSUSHITA T, KABA RA, VOZZI C, COPPEN SR, KHAN N, KAPRIELIAN R, YACOUB MH, SEVERS NJ: Altered connexin expression in human congestive heart failure. J Mol Cell Cardiol 33: 359-371, 2001.

EMDAD L, UZZAMAN M, TAKAGISHI Y, HONJO H, UCHIDA T, SEVERS NJ, KODAMA I, MURATA Y: Gap junction remodeling in hypertrophied left ventricles of aortic-banded rats: prevention by angiotensin II type 1 receptor blockade. J Mol Cell Cardiol 33: 219-231, 2001. 
FIALOVÁ M, DLUGOŠOVÁ K, OKRUHLICOVÁ L, KRISTEK F, MANOACH M, TRIBULOVÁ N: Adaptation of the heart to hypertension is associated with maladaptive gap junction connexin-43 remodeling. Physiol Res 57: 7-11, 2008.

FORMIGLI L, IBBA-MANNESCHI L, PERNA AM, PACINI A, POLIDORI L, NEDIANI C, MODESTI PA, NOSI D, TANI A, CELLI A, NERI-SERNERI GG, QUERCIOLI F, ZECCHI-ORLANDINI S: Altered Cx43 expression during myocardial adaptation to acute and chronic volume overloading. Histol Histopathol 18: 359369, 2003.

HAEFLIGER JA, CASTILlO E, WAEBER G, AUBERT JF, NICOD P, WAEBER B, MEDA P: Hypertension differentially affects the expression of the gap junction protein connexin43 in cardiac myocytes and aortic smooth muscle cells. Adv Exp Med Biol 432: 71-82, 1997a.

HAEFLIGER JA, CASTILlO E, WAEBER G, BERGONZELli GE, AUBERT JF, SUTTER E, NICOD P, WAEBER B, MEDA P: Hypertension increases connexin43 in a tissue-specific manner. Circulation 95: 10071014, 1997b.

HAEFLIGER JA, MEDA P, FORMENTON A, WIESEL P, ZANCHI A, BRUNNER HR, NICOD P, HAYOZ D: Aortic connexin43 is decreased during hypertension induced by inhibition of nitric oxide synthase. Arterioscler Thromb Vasc Biol 19: 1615-1622, 1999.

KAPRIELIAN RR, GUNNING M, DUPONT E, SHEPPARD MN, ROTHERY SM, UNDERWOOD R, PENNELL DJ, FOX K, PEPPER J, POOLE-WILSON PA, SEVERS NJ: Downregulation of immunodetectable connexin 43 and decreased gap junction size in the pathogenesis of chronic hibernation in the human left ventricle. Circulation 97: 651-660, 1998.

KOSTIN S, RIEGER M, DAMMER S, HEIN S, RICHTER M, KLOVEKORN WP, BAUER EP, SCHAPER J: Gap junction remodeling and altered connexin43 expression in the failing human heart. Mol Cell Biochem 242: 135-144, 2003.

MATSUSHITA T, OYAMADA M, FUJIMOTO K, YASUDA Y, MASUDA S, WADA Y, OKA T, TAKAMATSU T: Remodeling of cell-cell and cell-extracellular matrix interactions at the border zone of rat myocardial infarcts. Circ Res 85: 1046-1055, 1999.

MITAŠÍKOVÁ M, ŠMÍDOVÁ S, MACSALIOVÁ A, KNÉZL V, DLUGOŠOVÁ K, OKRUHLICOVÁ L, WEISMANN P, TRIBULOVÁ N: Aged male and female spontaneously hypertensive rats benefit from n-3 polyunsaturated fatty acids supplementation. Physiol Res 57 (Suppl 2): S39-S48, 2008.

PETERS NS: New insights into myocardial arrhythmogenesis: distribution of gap-junctional coupling in normal, ischaemic and hypertrophied human hearts. Clin Sci (Lond) 90: 447-452, 1996.

PETERS NS, WIT AL: Gap junction remodeling in infarction: does it play a role in arrhythmogenesis? J Cardiovasc Electrophysiol 11: 488-490, 2000.

PETERS NS, GREEN CR, POOLE-WILSON PA, SEVERS NJ: Reduced content of connexin43 gap junctions in ventricular myocardium from hypertrophied and ischemic human hearts. Circulation 88: 864-875, 1993.

PETERS NS, COROMILAS J, SEVERS NJ, WIT AL: Disturbed connexin43 gap junction distribution correlates with the location of reentrant circuits in the epicardial border zone of healing canine infarcts that cause ventricular tachycardia. Circulation 95: 988-996, 1997.

SAFFITZ JE, SCHUESSLER RB, YAMADA KA: Mechanisms of remodeling of gap junction distributions and the development of anatomic substrates of arrhythmias. Cardiovasc Res 42: 309-317, 1999.

SEPP R, SEVERS NJ, GOURDIE RG: Altered patterns of cardiac intercellular junction distribution in hypertrophic cardiomyopathy. Heart 76: 412-417, 1996.

SEVERS NJ, ROTHERY S, DUPONT E, COPPEN SR, YEH HI, KO YS, MATSUSHITA T, KABA R, HALLIDAY D: Immunocytochemical analysis of connexin expression in the healthy and diseased cardiovascular system. Microsc Res Tech 52: 301-322, 2001.

SMITH JH, GREEN CR, PETERS NS, ROTHERY S, SEVERS NJ: Altered patterns of gap junction distribution in ischemic heart disease. An immunohistochemical study of human myocardium using laser scanning confocal microscopy. Am J Pathol 139: 801-821, 1991.

TEUNISSEN BE, JONGSMA HJ, BIERHUIZEN MF: Regulation of myocardial connexins during hypertrophic remodelling. Eur Heart J 25: 1979-1989, 2004. 
TRIBULOVÁ N, DUPONT E, SOUKUP T, OKRUHLICOVÁ L, SEVERS NJ: Sex differences in connexin-43 expression in left ventricles of aging rats. Physiol Res 54: 705-708, 2005.

UZZAMAN M, HONJO H, TAKAGISHI Y, EMDAD L, MAGEE AI, SEVERS NJ, KODAMA I: Remodeling of gap junctional coupling in hypertrophied right ventricles of rats with monocrotaline-induced pulmonary hypertension. Circ Res 86: 871-878, 2000.

ZHUANG J, YAMADA KA, SAFFITZ JE, KLEBER AG: Pulsatile stretch remodels cell-to-cell communication in cultured myocytes. Circ Res 87: 316-322, 2000.

ZWEIFEL M, HIRSIGER H, MATOZAN K, WELLE M, SCHAFFNER T, MOHACSI P: Mast cells in ongoing acute rejection: increase in number and expression of a different phenotype in rat heart transplants. Transplantation 73: 1707-1716, 2002. 